\title{
EFISIENSI TEKNIS USAHA TANI PADI DI DESA MEUNASAH PANTON LABU KECAMATAN TANAH JAMBO AYE KABUPATEN ACEH UTARA
}

\author{
Devi Andriyani $^{\mathrm{a}^{*}}$, Mutia Fhazira ${ }^{\mathrm{a}^{*}}$ \\ ${ }^{a}$ Fakultas Ekonomi dan Bisnis Universitas Malikussaleh \\ *Corresponding author:devisep80@gmail.com \\ *mfhazira@gmail.com
}

ART I CLE I N F ORMATION

A B S T R A C T

Keywords:

DEA, technical efficiency, rice

\begin{abstract}
This study aims to analyze the technical efficiency of rice farming in Desa Meunasah Panton Labu, Tanah Jambo Aye Sub-district, North Aceh Regency. This study uses primary data obtained from the distribution of questionnaires to 50 respondents who are landowners and farmers in Desa Meunasah Panton Labu, Tanah Jambo Aye Subdistrict, North Aceh Regency. The study uses the Purposive sampling method. Data Envelopment Analysis (DEA) is used to analysis the data. The results showed that the landowners haping more technically efficient than farmers. From the Variable Ruturn Scale Approach (VRS) the study showed that 10 of farmers and 6 land owners were not eficient.
\end{abstract}

\section{PENDAHULUAN}

Indonesia merupakan negara yang kaya akan sumber daya alam yang ada di seluruh wilayah Indonesia. Indonesia juga termasuk negara agraris dimana sebagian besar mata pencaharian penduduknya adalah petani. Hingga saat ini sektor pertanian masih memberikan peran terhadap perekonomian nasional. Dalam mempertahankan penyediaan pangan nasional Indonesia mengalami peningkatan produksi padi. Sebanyak $75 \%$ masukan kalori harian masyarakat Indonesia berasal dari beras.

Beras merupakan produk pertanian yang memiliki peranan besar dalam kehidupan masyarakat indonesia karena beras merupakan pangan pokok sebagian besar masyarakat indonesia. Sebagai negara agraris yang juga merupakan negara produsen beras terbesar ketiga di dunia, indonesia ternyata menempati posisi tertinggi di dunia dalam hal konsumsi beras (USDA, 2011).

Meskipun Indonesia adalah negara terbesar ketiga yang memproduksi beras terbanyak di dunia, Indonesia masih tetap perlu mengimpor beras hampir setiap tahun (walau biasanya hanya untuk menjaga tingkat cadangan beras). Situasi ini disebabkan karena petani menggunakan teknikteknik pertanian yang tidak optimal ditambah dengan konsumsi per kapita beras yang besar (oleh populasi yang besar). Bahkan Indonesia memiliki salah satu konsumsi beras per kapita terbesar di seluruh dunia. Konsumsi beras per kapita di Indonesia tercatat hampir 150 kilogram (beras, per orang, per tahun) pada tahun 2017. Hanya Myanmar, Vietnam, dan Bangladesh yang memiliki konsumsi beras per kapita yang lebih tinggi dibanding Indonesia.

Produksi beras di Indonesia didominasi oleh para petani kecil, bukan oleh perusahaan besar yang dimiliki swasta atau negara. Para petani kecil mengkontribusikan sekitar $90 \%$ dari produksi total beras di Indonesia. Setiap petani itu memiliki lahan rata-rata kurang dari 0,8 hektar. Pertanian sebaiknya tidak lagi dipandang sebagai usaha tradisional yang berskala kecil. Pertanian seharusnya lebih dipandang sebagai suatu usaha yang apabila dijalankan dan dikelola dengan baik maka akan sangat menguntungkan, sehingga produk yang dihasilkan mempunyai kualitas yang mampu bersaing. Untuk itu usaha tani tidak saja memerlukan teknologi pertanian yang mampu meningkatkan kualitas, tetapi juga memerlukan manajemen yang baik dalam pengelolaannya.

Adapun salah satu dari 10 provinsi penghasil beras tertinggi di Indonesia adalah provinsi Aceh (NAD), produksi padi Aceh mencapai 2,5 juta ton, meningkat 13,5 persen atausetara 300.000 ton, dibanding tahun2016 (BPS Provinsi Aceh, 2017).

Dari 47 desa di Kecamatan Tanah Jambo Aye, desa Mns Panton Labu yaitu salah satu desa yang mempunyai luas lahan tebesar yaitu $65 \mathrm{Ha}$, dengan jumlah penduduk 4.420 jiwa, dan yang bekerja di bidang pertanian 385 jiwa.Yang terdiri dari petani pemilik dan petani penggarap. Petani pemilik Lahan ialah petani yang mempunyai lahan 
dan mengusahakannya sendiri. Sedangkan petani penggarap ialah petani yang mengusahakan tanah orang lain dengan sistem bagi hasil (BPS Aceh Utara, 2016).

Seringkali perbedaan kepemilikan lahan pertanian menyebabkan adanya perbedaan motivasi petani dalam mengerjakan usaha taninya. Dalam hal upaya meningkatkan produksi misalnya, antara petani pemilik lahan dengan petani penggarap dapat terjadi motivasi yang berbeda, dimana petani pemilik lahan akan menjalankan usahanya dengan sebaik-baiknya, baik untuk mendapatkan hasil produksi yang maksimal, maupun dalam menjaga unsur hara tanah agar dapat terjadinya proses pertanian yang berkelanjutan, dan tentunya akan selalu berusaha lebih untuk mendapatkan hasil yang lebih maksimal karena semua keuntungan akan dinikmati sepenuhnya tanpa harus berbagi hasil.

Sedangkan bagi petani penggarap tidak begitu termotivasi seperti motivasi yang dimiliki oleh petani pemilik lahan karena merasa tidak seluruh produksi akan dinikmati sendiri, namun harus berbagi dengan pemilik lahan. Tetapi petani penggarap juga akan melakukan usaha yang maksimal untuk meningkat hasil produksinya, tanpa memperdulikan keadaan unsur hara tanah untuk masa yang akan datang. Dan untuk meningkatkan hasil produksi, maka diperlukan penggunaan sarana produksi (pupuk, insektisida dan benih) yang tepat sasaran dan tepat waktu.

Namun karena adanya perbedaan motivasi yang akan mempengaruhi kinerja petani maka akan menyebabkan penggunaan sarana produksi yang berbeda. Karenanya dilakukan beberapa observasi awal untuk meneliti efisiensi dari usaha tani padi di desa Mns Panton Labu.

Berikut disajikan tabel penggunaan pupuk, insektisida, benih dan hasil produksi petani pemilik lahan dan petani penggarap dengan luas lahan seluas $2500 \mathrm{~m}$.

\section{Tabel 1}

\section{Penggunaan Pupuk, Insektisida, Benih dan Hasil Produksi Petani Pemilik Lahan dan Petani Penggarapdengan Luas Lahan Seluas}

\begin{tabular}{|c|c|c|c|c|c|c|c|}
\hline \multirow[b]{2}{*}{$\begin{array}{l}\text { Jenis } \\
\text { Petani }\end{array}$} & \multirow[b]{2}{*}{ Nama } & \multirow[b]{2}{*}{$\begin{array}{c}\text { Prod } \\
\text { uksi } \\
(\mathbf{k g})\end{array}$} & \multicolumn{3}{|c|}{ Pupuk } & \multirow[b]{2}{*}{$\begin{array}{c}\text { Inse } \\
\text { ktisi } \\
\text { da } \\
(\mathrm{ml})\end{array}$} & \multirow[b]{2}{*}{$\begin{array}{c}\text { Beni } \\
\mathbf{h} \\
(\mathbf{k g})\end{array}$} \\
\hline & & & $\begin{array}{l}\text { Ur } \\
\text { ea } \\
(\mathbf{k} \\
\text { g) }\end{array}$ & $\begin{array}{l}\text { NPK } \\
\text { (kg) }\end{array}$ & $\begin{array}{l}\text { Sp- } \\
36 \\
(\mathrm{~kg})\end{array}$ & & \\
\hline \multirow{3}{*}{$\begin{array}{l}\text { Petani } \\
\text { Pengga } \\
\text { rap }\end{array}$} & Ibrahim & 2400 & 50 & 25 & 25 & 200 & 20 \\
\hline & Fauziah & 2800 & 50 & 50 & 50 & 284 & 20 \\
\hline & Nurlela & 2800 & 50 & 30 & 30 & 172 & 10 \\
\hline \multirow{3}{*}{$\begin{array}{l}\text { Petani } \\
\text { Pemilik } \\
\text { Lahan }\end{array}$} & $\begin{array}{l}\text { Nur } \\
\text { Wahidah }\end{array}$ & 2400 & 50 & 50 & 50 & 314 & 20 \\
\hline & Nurdin & 3200 & 30 & 30 & 30 & 142 & 10 \\
\hline & Muslem & 2800 & 50 & 50 & 30 & 254 & 20 \\
\hline
\end{tabular}

Sumber Data : Hasil Observasi Awal dengan Menggunakan Kuisioner

Berdasarkan tabel 1 di atas maka dapat kita lihat bahwa adanya variasi produksi dari penggunaan sarana produksi sehingga akan menyebabkan tingkat efisiensi yang berbeda. Seperti petani yang bernama Fauziah dan Nur Wahidah dengan penggunaan pupuk yang sama yaitu pupuk urea $50 \mathrm{~kg}$, NPK $50 \mathrm{~kg}$, Sp-36 $50 \mathrm{~kg}$ dan benih $20 \mathrm{~kg}$, namun menghasikan produksi yang berbeda yaitu ibu Fauziah mendapatkan hasil produksi sebesar $2800 \mathrm{~kg}$, sedangkan ibu Nur Wahidah mendapatkan hasil produksi sebesar 2400 $\mathrm{kg}$. Dan juga bisa kita lihat petani yang bernama Nurlela dan Nurdin dimana penggunaan 2 jenis pupuk yang sama yaitu NPK $30 \mathrm{~kg}, \mathrm{Sp}-3630 \mathrm{~kg}$ dan benih $10 \mathrm{~kg}$. Namun menghasikan produksi yang berbeda yaitu ibu Nurlela mendapatkan hasil produksi sebesar $2800 \mathrm{~kg}$, sedangkan bapak Nurdin mendapatkan hasil produksi sebesar 3200 $\mathrm{kg}$.

Tujuan penelitian ini adalah untuk Mengetahui perbandingan tingkat efisiensi teknis usahatani padi petani pemilik lahan dan petani penggarap di Desa Mns Panton Labu Kecamatan Tanah Jambo Aye Kabupaten Aceh Utara. bagian 2 dari penelitian ini akan membangun tinjauan pustaka, metode penelitiannya untuk membahas penelitian disajikan dibagian 3 selanjutnya hasil penelitian serta pembahasan menjadi bagian ke 4 dalam penelitian ini yang selanjutnya pada bagian akhir merupakan kesimpulan dan saran.

\section{TINJAUAN PUSTAKA \\ Produksi}

Menurut Lopang (2016) mengatakan bahwa produksi merupakan hasil akhir dari proses atau aktivitas ekonomi dengan memanfaatkan beberapa masukan atau input. Dengan pengertian ini dapat dipahami bahwa kegiatan produksi adalah mengkombinasikan berbagai input atau masukan untuk menghasilkan output.

Produksi dapat didefinisikan sebagai hasil dari suatu proses atau aktivitas ekonomi dengan memanfaatkan beberapa masukan (input). Dengan demikian, kegiatan produksi tersebut adalah mengombinasikan berbagai masukan untuk menghasilkan keluaran (Yull, 2014). Secara sederhana produksi dapat dikatakan sebagai kegiatan yang ditujukan untuk menghasilkan dan menambah nilai suatu barang.

Pengertian produksi yang dikemukakan oleh International Labor Organization adalah suatu hasil dari input komponen utama(Lopang, 2016). 
Hasil penelitian (Nurung, 2002) mengemukakan hasil dari penelitian faktor produksi yang tidak nyata yaitu pupuk urea (X2) dengan nilai elastisitas $=-0,019$ dengan nilai $\mathrm{t}$ hitung $=0,446$, dan pestisida (X5) dengan nilai elastisitas $=-6,220 \mathrm{E}-03$ dengan nilai $\mathrm{t}$ hitung $=$ 0,079 , maka dari itu diperlukan peranan penyuluh pertanian dalam memberikan informasi kepada petani dalam menggunakan input secara tepat.

\section{Benih}

Bibit/benih adalah jumlah benih padi yang digunakan oleh seluruh petani dalam proses usaha tani dari seluruh wilayah kabupaten dan kota, dinyatakan dalam satuan $\mathrm{kg}$ (Triyanto, 2006).

Benih adalah bahan tanaman yang berasal dari generatif maupun vegetatif yang digunakan untuk tujuan mengembangbiakkan tanaman hutan (Permenhut P.1/Menhut-II/2009).

Penggunaan benih yang baik dan sesuai dengan aturan akan menghasilkan tanaman budidaya yang baik secara kualitas maupun kuantitas. Penggunaan benih yang terlalu banyak menyebabkan populasi perlubang tanaman tinggi sehingga adanya persaingan dalam penyerapan unsur hara, oksigen dan sinar matahari yang mengakibatkan penurunan produksi (Respikasari et al., 2014).

Benih merupakan media tanam yang akan digunakan oleh dalam proses usaha tani dari seluruh wilayah kabupaten dan kota, dinyatakan dalam satuan kg. Penggunaan benih yang baik dan sesuai dengan aturan akan menghasilkan tanaman budidaya yang baik

Hasil penelitian (Muhaimin, menunjukkan bahwa input bibit secara signifikan berpengaruh terhadap produksi padi organik di Kecamatan Pakis. Penelitian (Darwanto, 2010) juga menunjukkan hasil bahwa input bibit berpengaruh positif terhadap produksi padi di Provinsi Jawa Tengah.

\section{Pupuk}

Pupuk adalah material yang ditambahkan pada media tanam atau tanaman untuk mencukupi kebutuhan hara yang diperlukan tanaman sehingga mampu berproduksi dengan baik (Anonymous, 2012).

Pupuk organik adalah pupuk yang berasal dari alam, yang berupa sisasisa organisme hidup baik sisa tanaman maupun sisa hewan. Pupuk organik mengandung unsur-unsur hara baik makro maupun mikro yang dibutuhkan oleh tumbuhan, supaya dapat tumbuh dengan subur. Beberapa jenis pupuk yang termasuk pupuk organik adalah pupuk kandang, pupuk hijau, kompos dan pupuk guano (Handayani dkk, 2011).

Pupuk merupakan nutrisi atau bahan makanan yang akan diberikan kepada tanaman. Pupuk merupakan sarana dan kunci sukses dari kesuburan tanah serta keberhasilan petani dalam meningkatkan produksi tanaman, sehingga pupuk sangat berpengaruh terhadap produksi.

Adapun jenis-jenis pupuk nya yaitu pupuk urea, pupuk NPK, dan pupuk SP-36. Pemupukan dilakukan seminggu setelah tanam untuk jenis pupuk Urea dan pupuk SP-36, sedangkan pupuk NPK digunakan dua minggu setelah masa tanam.

Hasil penelitian Fajar Firmana et al., (2014) Variabel lainnya yang memiliki pengaruh signifikan terhadap efisiensi teknis dari usahatani padi yaitu penggunaan pupuk organik pada taraf nyata $15 \%$. Nilai koefisien dari variabel penggunaan pupuk organik memiliki nilai yang positif. Hal ini menunjukkan bahwa semakin banyak penggunaan pupuk organik, maka akan meningkatkan efisiensi teknis dari usahatani yang dilakukan oleh petani. Hasil penelitian ini sejalan dengan penelitian Patil et al., (2013) dan Oraye et al., (2012), dimana penggunaan pupuk organik dapat mengurangi penggunaan pupuk anorganik dan memberikan pengaruh terhadap kesuburan tanah dengan adanya penerapan pemupukan berimbang.

\section{Insektisida}

Menurut Sudarmo (2005), insektisida adalah substansi kimia yang digunakan untuk membunuh atau mengendalikan hama. insektisida sangat dibutuhkan petani untuk mencegah serta membasmi hama dan penyakit tanaman yang dibudidayakan.

Insektisida dapat menguntungkan usahatani namun di sisi lain insektisida dapat merugikan petani. Insektisida dapat menjadi kerugian bagi petani jika terjadi kesalahan pemakaian baik dari cara maupun komposisi yang diaplikasikan ke tanaman. Pemakaian yang berlebihan dapat menyebabkan biaya produksi yang berlebihan (Purwono, 2007).

Insektisida merupakanzat kimia yang beracun yang bisa digunakan untuk membunuh semua jenis serangga atau hama yang menjadi pengganggu bagi tanaman. Dalam pemakaian insektisida harus memperhatikan dosis maupun ukurannya. Penggunaan insektisida dilakukan 7 atau 10 hari sesudah masa tanam dengan menggunakan dosis terendah dan selanjutnya dilakukan disaat padi mulai terlihat mengalami gangguan dari hama. 
Hal penelitian (Anonim, 2008), yang menyatakan bahwa dengan menggunakan insektisida dengan dosis berlebihan akan mengakibatkan musnahnya musuh alami dari hama/penyakit.

Hasil penelitian (Ambarawati dkk, 2012) menunjukkan bahwa input pupuk Urea, pupuk NPK (Phosnka dan Pelangi), pupuk organik dan tenaga kerja sudah efisien, sedangkan secara ekonomis penggunaan pestisida tidak efisien, maka perlu mengurangi jumlah penggunaan secara tepat jenis, dosis, waktu dan cara pemberian sehingga menghasilkan produksi padi yang optimal dan petani memperoleh keuntungan yang maksimum.

\section{Hipotesis}

Hipotesis merupakan jawaban sementara atau kesimpulan sementara dari masalah penelitian. Dalam penelitian ini yang menjadi hipotesisnya adalah sebagai berikut :

HO : Diduga penggunaan Input Benih, Pupuk dan Insektisida tidak efisien dalam menghasilkan output Produksi di Desa Kecamatan Tanah Jambo Aye Kabupaten Aceh Utara.

Ha : Diduga penggunaan Input Benih, Pupuk dan Insektisida efisien dalam menghasilkan output produksi di Desa Kecamatan Tanah Jambo Aye Kabupaten Aceh Utara

\section{METODE PENELITIAN}

\section{Populasi dan Sampel}

Populasi dalam penelitian ini adalah seluruh petani pemilik lahan dan petani penggarap di Desa Mns Panton Labu yaitu sebanyak 385 petani (Sumber : Statistik Kecamatan, 2017)

Tekhnik pengambilan sampel dilakukan dengan metode purposive sampling, yaitu cara pengambilan sampel yang didasarkan pada pertimbangan-pertimbangan tertentu, terutama pertimbangan yang diberikan oleh sekelompok pakar atauexpert(Sanusi, 2011).

Dengan memenuhi

Karakteristik-

karakteristik tertentu, Yaitu :

1. Petani penggarap yang memiliki luas lahan $2.500 \mathrm{~m}^{2}$.

2. Petani pemilik lahan yang memiliki luas lahan $2.500 \mathrm{~m}^{2}$.

3. Petani yang memiliki kedua ciri-ciri diatas, namun yang menggunakan jenis pupuk Urea, NPK, dan SP-36.

Berdasarkan Observasi awal dan informasi dari Aparat desa maka petani di desa Mns Pnton Labu yang memenuhi karakteristik-karakteristik diatas adalah sebanyak 50 petani, sehingga jumlah sampel dalam penelitian ini yaitu 50 petani.

\section{Metode Analisis Data}

Metode analisis data yang digunakan dalam penelitian ini menggunakan jenis penelitian deskriptif. Untuk menganalisis efisiensi penggunaan benih, pupuk dan insektisida oleh para petani baik petani pemilik lahan maupun petani penggarap di Desa Mns Panton Labu Kecamatan Tanah Jambo Aye Kabupaten Aceh Utara. Penelitian ini menggunakan Metode DEA (Data envelopment analysis). Yaitu suatu metode untuk mengevaluasi dan memecahkan masalah dengan cara mengintregrasikan beberapa masukan dan keluaran.

DEA yang dirancang oleh Cooper, Seiford dan Tone (2000) bertujuan untuk mengukur efisiensi atau produktivitas dari DMU (Decision Making Unit) tertentu (Ramanathan, 2003). DMU atau unit pengambil keputusan dapat termasuk manufaktur, departemen organisasi besar seperti universitas, sekolah, bank, rumah sakit, pembangkit listrik, kantor terlatih seperti praktisi medis. DEA telah berhasil diterapkan untuk mngukur kinerja fisiensi semua jenis DMU.

DEA merupakan suatu metodologi yang digunakan untuk mengevaluasi efisiensi dari suatu unit pengambilan keputusan (unit kerja) yang bertanggung jawab menggunakan sejumlah input untuk memperoleh suatu output yang ditargetkan. DEA merupakan model pemrograman fraksional yang bisa mencakup banyak input dan output, tanpa perlu penjelasan eksplisit mengenai hubungan fungsional antara input dan output. DEA menghitung ukuran efisiensi secara scalar dan menentukan level input dan output yang efisien untuk unit yang dievaluasi.

Pengukuran efisiensi dengan menggunakan metode DEA dapat dilakukan dengan cara, menentukan variabel-variabel input dan output. Selanjutnya menentukan orientasi model, apakah bertujuan untuk meminimalkan input atau memaksimalkan output. Hubungan variabel input dengan output apakah bersifat Constant return to scale (CRS) atau Variabel return to scale (VRS) merupakan aspek yang penting dalam teknik DEA.

\section{Pengujian Efisiensi Menggunakan Pendekatan Variabel Return to Scale (VRS)}

Pendekatan ini berasumsi bahwa rasio antara penambahan input dan output tidak sama (variable return to scale). Artinya, penambahan input sebesar $\mathrm{n}$ kali tidak akan menyebabkan output meningkat sebesar $\mathrm{n}$ kali, bisa lebih kecil 
atau lebih besar dari n kali. Peningkatan proporsi bisa bersifat increasing return to scale (IRS) atau bisa juga bersifat decreasing return to scale (DRS). Hasil model ini menambahkan kondisi convexity bagi nilai-nilai bobot $\lambda$, dengan memasukkan dalam model batasan berikut:

$$
\sum_{j=1}^{n} \lambda j=1
$$

Selanjutnya model BCC dapat ditulis dengan persamaan berikut: $\lambda$

$\operatorname{Max} \pi$ (Efisiensi DMU Model VRS)

Subject to:

$\sum_{j=1}^{n} x i j$

$\sum_{j=1}^{n} y r j \quad \lambda i j \geq \pi i o$
$\sum_{j=1}^{n} \lambda j \geq 1$

$\mathrm{i}=1,2, \ldots ., \mathrm{m}$

$\mathrm{r}=1,2, \ldots, \mathrm{s}$

$\mathrm{j}=1,2, \ldots ., \mathrm{n}$

Dimana:

$\begin{array}{ll}\pi & =\text { Efisiensi DMU Model VRS } \\ \mathrm{n} & =\text { Jumlah DMU } \\ \mathrm{m} & =\text { Jumlah Input } \\ \mathrm{s} & =\text { Jumlah Output } \\ \mathrm{xij} & =\text { Jumlah Input ke-i DMU j } \\ \mathrm{yrj} & =\text { Jumlah Output ke- } \mathrm{r} \text { DMU j } \\ \lambda \mathrm{j} & =\text { Bobot DMU j untuk DMU yang dihitung }\end{array}$

\section{HASIL PENELITIAN DAN PEMBAHASAN}

Metode Analisis Data

Penelitian ini menggunakan alat analisis DEA, dengan software DEAP version 2.1, dimana menggunakan pendekatan Variabel Return to Scale (VRS) yang berorientasi pada pendekatan input. Berdasarkan hasil perhitungan efisiensi menggunakan DEA, tingkat efisiensi pada petani penggarap dan petani pemilik lahan di Desa Meunasah Panton Labu dengan jumlah sampel 50 orang dengan petani penggarap 25 orang dan petani pemilik lahan juga 25 orang.

\section{Hasil Pengolahan data Variabel Return to Scale (VRS) - Input Oriented Petani Penggarap}

Berdasarkan tabel 4.2 dapat dilihat dimana nilai 1.000 menunjukkkan bahwa responden berada pada garis frontier, dengan kata lain bernilai efisien.
Tabel 2

Hasil Olah Data Envelopment Analysis (DEA) Petani Penggarap dengan Pendekatan Variabel Return to Scale (VRS)

\begin{tabular}{|c|c|c|}
\hline No & Nama Responden & Tingkat Efisiensi \\
\hline 1. & Ibrahim & 1.000 \\
\hline 2. & Fauziah & 0.600 \\
\hline 3. & Nur Lela & 1.000 \\
\hline 4. & Nursiah & 0.808 \\
\hline 5. & Usman & 0.990 \\
\hline 6. & Nazaruddin & 1.000 \\
\hline 7. & Nilawati & 0.965 \\
\hline 8. & Lindawati & 1.000 \\
\hline 9. & Maulina & 0.667 \\
\hline 10. & Zuraida & 0.737 \\
\hline 11. & Juliana & 1.000 \\
\hline 12. & Amirullah & 1.000 \\
\hline 13. & Nur Aini & 1.000 \\
\hline 14. & Abdul Manan & 1.000 \\
\hline 15. & Fatimah Zuhra & 1.000 \\
\hline 16. & Raziah Hasyim & 0.627 \\
\hline 17. & Muhammad Yusuf & 0.882 \\
\hline 18. & Aurizawati & 1.000 \\
\hline 19. & Marni & 1.000 \\
\hline 20. & Raimah & 1.000 \\
\hline 21. & Ismail & 1.000 \\
\hline 22. & Rusmawarni & 1.000 \\
\hline 23. & M.Saleh & 1.000 \\
\hline 24. & Zainun & 0.627 \\
\hline \multirow[t]{2}{*}{25.} & Luqman Nafi & 0.600 \\
\hline & Rata-rata & 0.900 \\
\hline
\end{tabular}

Pada tabel 2 diatas dapat dilihat bahwaPetani penggarap di Desa Meunasah Panton Labu 15 petani responden yang bernilai efisien yaitu Ibrahim, Nur Lela, Nazaruddin, Lindawati, Juliana, Amirullah, Nur Aini, Abdul Manan, Fatimah Zuhra, Aurizawati, Marni, Raimah, Ismail, Rusmawarni, dan M. Saleh.

Sedangkan yang tidak efisien ada 10 petani responden yaitu Fauziah, Nursiah, Usman, Nilawati, Maulina, Zuraida, Raziah Hasyim, Muhammad Yusuf, Zainun dan Luqman Nafi karena nilainya $<1.000$.

Hasil Pengolahan data Variabel Return to Scale (VRS) - Input Oriented Petani Pemilik Lahan

Berdasarkan tabel 4.3 dapat dilihat dimana nilai 1.000 menunjukkkan bahwa responden berada pada garis frontier, dengan kata lain bernilai efisien.

Tabel 3

Hasil Olah Data Envelopment Analysis (DEA) Petani Pemilik lahan dengan Pendekatan Variabel Return to Scale (VRS)

\begin{tabular}{|l|l|c|}
\hline No & Nama Responden & Tingkat Efisiensi \\
\hline 1. & Nur Wahidah & 0.531 \\
\hline 2. & Nurdin & 1.000 \\
\hline 3. & Muslem & 0.531 \\
\hline
\end{tabular}




\begin{tabular}{|l|l|l|}
\hline 4. & M.Yusuf & 1.000 \\
\hline 5. & Sabidah & 1.000 \\
\hline 6. & Salamiah & 1.000 \\
\hline 7. & Halim & 1.000 \\
\hline 8. & Iskandar & 1.000 \\
\hline 9. & Nur Baidah & 0.807 \\
\hline 10. & Ibrahim Ali & 1.000 \\
\hline 11. & Safrina & 1.000 \\
\hline 12. & Aminah & 1.000 \\
\hline 13. & Zainab & 1.000 \\
\hline 14. & Halimah & 1.000 \\
\hline 15. & Aisyah & 1.000 \\
\hline 16. & Wardiah & 1.000 \\
\hline 17. & Sariyani & 1.000 \\
\hline 18. & Heriyati & 0.717 \\
\hline 19. & Abdul Jalil & 1.000 \\
\hline 20. & Rahmaniah & 0.760 \\
\hline 21. & Hasanah & 1.000 \\
\hline 22. & Nurjannah & 0.541 \\
\hline 23. & Bakhtiar & 1.000 \\
\hline 24. & Nur Jalilah & 1.000 \\
\hline 25. & M. Yunus & 1.000 \\
\hline & Rata-rata & $\mathbf{0 . 9 1 6}$ \\
\hline & & \\
\hline
\end{tabular}

Berdasarkan tabel 3 di atas dapat dilihat bahwa Petani pemilik lahan di Desa Meunasah Panton Labu 19 petani responden yang bernilai efisien yaitu Nurdin, M. Yusuf, Sabidah, Salamiah, Halim, Iskandar, Ibrahim Ali, Safrina, Aminah, Zainab, Halimah, Aisyah, Wardiah, Sariyani, Abdul Jalil, Hasanah, Bakhtiar, Nur Jalilah, dan M. Yunus.

Sedangkan yang tidak efisien Nur Wahidah, Muslem, Nur Baidah, Heriyati, Rahmaniah, dan Nur Jannah karena nilainya $<1.000$.

Dari kedua petani tersebut yaitu petani penggarap dan petani pemilik lahan yang paling efisien dilihat dari VRS adalah petani pemilik lahan dikarenakan 19 petani responden yang efisien sedangkan petani penggarap 14 petani responden yang efisien.

\section{Pembahasan}

Pada bagian ini memuat pembahasan mengenai tingkat inefisiensi yang dilihat dari penggunaan input, pada usaha tani padi petani penggarap dan petani pemilik lahan di desa Meunasah Panton Labu berdasarkan hasil perhitungan efisiensi DEA dan cara menangani input yang inefisiensi agar menjadi efisien.

\section{Upaya peningkatan efisiensi Petani Penggarap di Desa Meunasah Panton Labu}

Berdasarkan hasil pengujian yang telah dilakukan dapat dilihat bahwa nilai skala efisiensi pada petani penggarap di desa Meunasah Panton Labu yang berada dibawah angka satu $(<1)$ ada 10 petani penggarap yaitu Fauziah, Nursiah, Usman, Nilawati, Maulina, Zuraida, Raziah Hasyim, Muhammad Yusuf, Zainun dan Luqman Nafi.

\section{Fauziah}

Berdasarkan pengujian yang telah dilakukan petani yang bernama Fauziah belum mencapai skala yang efisien, dikarenakan penggunaan input yang belum maksimal, sehingga menyebabkan output yang dihasilkan juga belum maksimal.

Berikut dapat dilihat pada tabel 4.5 tingkat inefisiensi ibu Fauziah, berdasarkan masing-masing variabel input yang digunakan dalam usaha tani padi.

\section{Tabel 4}

Nilai Original, Target, Radial Movement dan Slack Movement Input Output Ibu Fauziah yang inefisiensi dengan tingkat efisiensi 0.600

\begin{tabular}{|l|cccc|}
\hline \multicolumn{1}{|c}{ Variabel } & $\begin{array}{c}\text { Original } \\
\text { value }\end{array}$ & $\begin{array}{c}\text { Target } \\
\text { value }\end{array}$ & $\begin{array}{c}\text { Radial } \\
\text { movement }\end{array}$ & $\begin{array}{c}\text { Slack } \\
\text { movement }\end{array}$ \\
\hline Produksi & 2800.000 & 3400.000 & 0.000 & 600.000 \\
Pupuk Urea & 50.000 & 30.000 & -20.000 & 0.000 \\
Pupuk NPK & 50.000 & 30.000 & -20.000 & 0.000 \\
Pupuk SP-36 & 50.000 & 10.000 & -20.000 & -20.000 \\
Insektisida & 284.000 & 84.000 & -113.600 & -86.400 \\
Benih & 20.000 & 10.000 & -8.000 & -2.000 \\
\hline
\end{tabular}

Sumber : Hasil olah data, 2019

Pada tabel 4 di atas dapat dijelaskan penggunaan input ibu Fauziah mengalami inefisiensi pada seluruh input yang digunakan yaitu pupuk Urea, pupuk NPK, pupuk SP-36, insektisida dan benih.

Variabel input pertama dan kedua yaitu pupuk urea dan pupuk NPK memiliki original value sebesar $50 \mathrm{~kg}$ dengan target value sebesar $30 \mathrm{~kg}$. Terlihat bahwa original value lebih tinggi dari pada target value, maka agar penggunaan pupuk urea dan pupuk NPK lebih efisien harus dikurangi sebesar $20 \mathrm{~kg}$ dengan slack movement sebesar 0.

Original value yang dimiliki oleh variabel input ketiga yaitu pupuk SP-36 sebesar $50 \mathrm{~kg}$ dan target value nya sebesar $10 \mathrm{~kg}$. Maka untuk lebih mengefisiensikan penggunaan pupuk SP-36 harus dikurangi sebesar $20 \mathrm{~kg}$.

Variabel input keempat yaitu insektisida memiliki original value sebesar $284 \mathrm{ml}$ dengan target value sebesar $84 \mathrm{ml}$. Terlihat bahwa original value lebih tinggi dari pada target value, maka agar penggunaan insektisida lebih efisien harus dikurangi sebesar $113.6 \mathrm{ml}$.

Variabel input kelima yaitu benih memiliki original value sebesar $20 \mathrm{~kg}$ dengan target value sebesar $10 \mathrm{~kg}$. Terlihat bahwa original value lebih tinggi dari pada target value, maka agar penggunaan benih lebih efisien harus dikurangi sebesar $8 \mathrm{~kg}$.

\section{Nursiah}

Berdasarkan pengujian yang telah dilakukan petani yang bernama Nursiah belum mencapai skala yang efisien, dikarenakan penggunaan input yang belum maksimal, sehingga menyebabkan output yang dihasilkan juga belum maksimal.

Berikut dapat dilihat pada tabel 4.6 tingkat inefisiensi ibu Nursiah, berdasarkan masing-masing variabel input yang digunakan dalam usaha tani padi. 
Tabel 5

Nilai Original, Target, Radial Movement dan Slack Movement Input Output Ibu Nursiah yang inefisiensi dengan tingkat efisiensi 0.808

\begin{tabular}{|l|cccc|}
\hline \multicolumn{1}{|c|}{ Variabel } & $\begin{array}{c}\text { Original } \\
\text { value }\end{array}$ & $\begin{array}{c}\text { Target } \\
\text { value }\end{array}$ & $\begin{array}{c}\text { Radial } \\
\text { movement }\end{array}$ & $\begin{array}{c}\text { Slack } \\
\text { movement }\end{array}$ \\
\hline Produksi & 2600.000 & 3400.000 & 0.000 & 800.000 \\
Pupuk Urea & 50.000 & 30.000 & -9.615 & -10.385 \\
Pupuk NPK & 50.000 & 30.000 & -9.615 & -10.385 \\
Pupuk SP- & 50.000 & 10.000 & -9.615 & -30.385 \\
36 & 104.000 & 84.000 & -20.000 & 0.000 \\
Insektisida & 20.000 & 10.000 & -3.846 & -6.154 \\
Benih & 2000 & & \\
\hline
\end{tabular}

Sumber : Hasil olah data, 2019

Pada tabel 5 diatas dapat dijelaskan penggunaan input ibu Nursiah mengalami inefisiensi pada seluruh input yang digunakan yaitu pupuk Urea, pupuk NPK, pupuk SP-36, insektisida dan benih.

Variabel input pertama dan kedua yaitu pupuk urea dan pupuk NPK memiliki original value sebesar $50 \mathrm{~kg}$ dengan target value sebesar $30 \mathrm{~kg}$. Terlihat bahwa original value lebih tinggi dari pada target value, maka agar penggunaan pupuk urea dan pupuk NPK lebih efisien harus dikurangi sebesar $9.615 \mathrm{~kg}$

Original value yang dimiliki oleh variabel input ketiga yaitu pupuk SP-36 sebesar $50 \mathrm{~kg}$ dan target value nya sebesar $10 \mathrm{~kg}$. Maka untuk lebih mengefisiensikan penggunaan pupuk SP-36 harus dikurangi sebesar $9.615 \mathrm{~kg}$.

Variabel input keempat yaitu insektisida memiliki original value sebesar $104 \mathrm{ml}$ dengan target value sebesar $84 \mathrm{ml}$. Terlihat bahwa original value lebih tinggi dari pada target value, maka agar penggunaan insektisida lebih efisien harus dikurangi sebesar $20 \mathrm{ml}$.

Variabel input kelima yaitu benih memiliki original value sebesar $20 \mathrm{~kg}$ dengan target value sebesar $10 \mathrm{~kg}$. Terlihat bahwa original value lebih tinggi dari pada target value, maka agar penggunaan benih lebih efisien harus dikurangi sebesar $3.846 \mathrm{~kg}$.

\section{Usman}

Berdasarkan pengujian yang telah dilakukan petani yang bernama Usman belum mencapai skala yang efisien, dikarenakan penggunaan input yang belum maksimal, sehingga menyebabkan output yang dihasilkan juga belum maksimal.Berikut dapat dilihat pada tabel 6 tingkat inefisiensi bapak Usman, berdasarkan masing-masing variabel input yang digunakan dalam usaha tani padi.

\section{Tabel 6}

Nilai Original, Target, Radial Movement dan Slack Movement Input Output Bapak Usman yang inefisiensi dengan tingkat efisiensi 0.990

\begin{tabular}{|c|cccc|}
\hline Variabel & $\begin{array}{c}\text { Original } \\
\text { value }\end{array}$ & $\begin{array}{c}\text { Target } \\
\text { value }\end{array}$ & $\begin{array}{c}\text { Radial } \\
\text { movement }\end{array}$ & $\begin{array}{c}\text { Slack } \\
\text { movement }\end{array}$ \\
\hline Produksi & 2800.000 & 3339.086 & 0.000 & 539.086 \\
Pupuk Urea & 50.000 & 31.218 & -0.508 & -18.274 \\
Pupuk NPK & 30.000 & 29.695 & -0.305 & 0.000
\end{tabular}

\begin{tabular}{|lllll|} 
Pupuk SP- & 30.000 & 10.914 & -0.305 & -18.782 \\
In & & & & 0.000 \\
Benih & 20.000 & 10.609 & -0.203 & -9.188 \\
\hline
\end{tabular}

Sumber : Hasil olah data, 2019

Pada tabel 6 di atas dapat dijelaskan penggunaan input bapak Usman mengalami inefisiensi pada seluruh input yang digunakan yaitu pupuk Urea, pupuk NPK, pupuk SP-36, insektisida dan benih.

Variabel input pertama yaitu pupuk urea memiliki original value sebesar $50 \mathrm{~kg}$ dengan target value sebesar $31 \mathrm{~kg}$. Terlihat bahwa original value lebih tinggi dari pada target value, maka agar penggunaan pupuk urea lebih efisien harus dikurangi sebesar $0.508 \mathrm{~kg}$.

Variabel input kedua yaitu pupuk NPK memiliki original value sebesar $30 \mathrm{~kg}$ dengan target value sebesar $29.7 \mathrm{~kg}$. Terlihat bahwa original value lebih tinggi dari pada target value, maka agar penggunaan pupuk NPK lebih efisien harus dikurangi sebesar $0.305 \mathrm{~kg}$.

Original value yang dimiliki oleh variabel input ketiga yaitu pupuk SP-36 sebesar $30 \mathrm{~kg}$ dan target value nya sebesar $11 \mathrm{~kg}$. Maka untuk lebih mengefisiensikan penggunaan pupuk SP-36 harus dikurangi sebesar $0.305 \mathrm{~kg}$.

Variabel input keempat yaitu insektisida memiliki original value sebesar $92 \mathrm{ml}$ dengan target value sebesar $91 \mathrm{ml}$. Terlihat bahwa original value lebih tinggi dari pada target value, maka agar penggunaan insektisida lebih efisien harus dikurangi sebesar $0.9 \mathrm{ml}$.

Variabel input kelima yaitu benih memiliki original value sebesar $20 \mathrm{~kg}$ dengan target value sebesar $11 \mathrm{~kg}$. Terlihat bahwa original value lebih tinggi dari pada target value, maka agar penggunaan benih lebih efisien harus dikurangi sebesar $0.2 \mathrm{~kg}$.

\section{Nilawati}

Berdasarkan pengujian yang telah dilakukan petani yang bernama Nilawati belum mencapai skala yang efisien, dikarenakan penggunaan input yang belum maksimal, sehingga menyebabkan output yang dihasilkan juga belum maksimal.

Berikut dapat dilihat pada tabel 7 tingkat inefisiensi ibu Nilawati berdasarkan masing-masing variabel input yang digunakan dalam usaha tani padi.

\section{Tabel 7}

Nilai Original, Target, Radial Movement dan Slack Movement Input Output Ibu Nilawati yang inefisiensi dengan tingkat efisiensi 0.965

\begin{tabular}{|l|cccc|}
\hline \multicolumn{1}{|c|}{ Variabel } & $\begin{array}{c}\text { Original } \\
\text { value }\end{array}$ & $\begin{array}{c}\text { Target } \\
\text { value }\end{array}$ & $\begin{array}{c}\text { Radial } \\
\text { movement }\end{array}$ & $\begin{array}{c}\text { Slack } \\
\text { movement }\end{array}$ \\
\hline Produksi & 3200.000 & 3200.000 & 0.000 & 0.000 \\
Pupuk Urea & 50.000 & 34.145 & -1.727 & -14.127 \\
Pupuk NPK & 30.000 & 28.964 & -1.036 & 0.000 \\
Pupuk SP- & 20.000 & 13.000 & -0.691 & -6.309 \\
36 & 112.000 & 108.131 & -3.869 & 0.000 \\
Insektisida & 15.000 & 12.000 & -0.518 & -2.482 \\
Benih & & & & \\
\hline
\end{tabular}


Sumber : Hasil olah data, 2019

Pada tabel 7 diatas dapat dijelaskan penggunaan input ibu Nilawati mengalami inefisiensi pada seluruh input yang digunakan yaitu pupuk Urea, pupuk NPK, pupuk SP-36, insektisida dan benih.

Variabel input pertama yaitu pupuk urea memiliki original value sebesar $50 \mathrm{~kg}$ dengan target value sebesar $34 \mathrm{~kg}$. Terlihat bahwa original value lebih tinggi dari pada target value, maka agar penggunaan pupuk urea lebih efisien harus dikurangi sebesar $1.8 \mathrm{~kg}$.

Variabel input kedua yaitu pupuk NPK memiliki original value sebesar $30 \mathrm{~kg}$ dengan target value sebesar $29 \mathrm{~kg}$. Terlihat bahwa original value lebih tinggi dari pada target value, maka agar penggunaan pupuk NPK lebih efisien harus dikurangi sebesar $1.036 \mathrm{~kg}$.

Original value yang dimiliki oleh variabel input ketiga yaitu pupuk SP-36 sebesar $20 \mathrm{~kg}$ dan target value nya sebesar $13 \mathrm{~kg}$. Maka untuk lebih mengefisiensikan penggunaan pupuk SP-36 harus dikurangi sebesar $0.7 \mathrm{~kg}$.

Variabel input keempat yaitu insektisida memiliki original value sebesar $112 \mathrm{ml}$ dengan target value sebesar $108 \mathrm{ml}$. Terlihat bahwa original value lebih tinggi dari pada target value, maka agar penggunaan insektisida lebih efisien harus dikurangi sebesar $3.9 \mathrm{ml}$.

Variabel input kelima yaitu benih memiliki original value sebesar $15 \mathrm{~kg}$ dengan target value sebesar $12 \mathrm{~kg}$. Terlihat bahwa original value lebih tinggi dari pada target value, maka agar penggunaan benih lebih efisien harus dikurangi sebesar $0.5 \mathrm{~kg}$.

\section{Maulina}

Berdasarkan pengujian yang telah dilakukan petani yang bernama Maulina belum mencapai skala yang efisien, dikarenakan penggunaan input yang belum maksimal, sehingga menyebabkan output yang dihasilkan juga belum maksimal.

Berikut dapat dilihat pada tabel 8 tingkat inefisiensi ibu Maulina berdasarkan masing-masing variabel input yang digunakan dalam usaha tani padi.

Tabel 8

Nilai Original, Target, Radial Movement dan Slack Movement Input Output Ibu Maulina yang inefisiensi dengan tingkat efisiensi 0.667

\begin{tabular}{|l|cccc|}
\hline \multicolumn{1}{|c|}{ Variabel } & $\begin{array}{c}\text { Original } \\
\text { value }\end{array}$ & $\begin{array}{c}\text { Target } \\
\text { value }\end{array}$ & $\begin{array}{c}\text { Radial } \\
\text { movement }\end{array}$ & $\begin{array}{c}\text { Slack } \\
\text { movement }\end{array}$ \\
\hline Produksi & 3200.000 & 3400.000 & 0.000 & 200.000 \\
Pupuk Urea & 50.000 & 30.000 & -16.667 & -3.333 \\
Pupuk NPK & 50.000 & 30.000 & -16.667 & -3.333 \\
Pupuk SP- & 30.000 & 10.000 & -10.000 & -10.000 \\
$\begin{array}{l}\text { Insektisida } \\
\text { Benih }\end{array}$ & 142.000 & 84.000 & -47.333 & -10.667 \\
\hline
\end{tabular}

Sumber : Hasil olah data, 2019

Pada tabel 8 diatas dapat dijelaskan penggunaan input ibu Maulina mengalami inefisiensi pada seluruh input yang digunakan yaitu pupuk Urea, pupuk NPK, pupuk SP-36, insektisida dan benih.

Variabel input pertama dan kedua yaitu pupuk urea dan pupuk NPK memiliki original value sebesar $50 \mathrm{~kg}$ dengan target value sebesar $30 \mathrm{~kg}$. Terlihat bahwa original value lebih tinggi dari pada target value, maka agar penggunaan pupuk urea dan pupuk NPK lebih efisien harus dikurangi sebesar $16.7 \mathrm{~kg}$.

Original value yang dimiliki oleh variabel input ketiga yaitu pupuk SP-36 sebesar $30 \mathrm{~kg}$ dan target value nya sebesar $10 \mathrm{~kg}$. Maka untuk lebih mengefisiensikan penggunaan pupuk SP-36 harus dikurangi sebesar $10 \mathrm{~kg}$.

Variabel input keempat yaitu insektisida memiliki original value sebesar $142 \mathrm{ml}$ dengan target value sebesar $84 \mathrm{ml}$. Terlihat bahwa original value lebih tinggi dari pada target value, maka agar penggunaan insektisida lebih efisien harus dikurangi sebesar $47.3 \mathrm{ml}$.

Variabel input kelima yaitu benih memiliki original value sebesar $15 \mathrm{~kg}$ dengan target value sebesar $10 \mathrm{~kg}$. Terlihat bahwa original value lebih tinggi dari pada target value, maka agar penggunaan benih lebih efisien harus dikurangi sebesar $5 \mathrm{~kg}$.

\section{Zuraida}

Berdasarkan pengujian yang telah dilakukan petani yang bernama Zuraida belum mencapai skala yang efisien, dikarenakan penggunaan input yang belum maksimal, sehingga menyebabkan output yang dihasilkan juga belum maksimal.

Berikut dapat dilihat pada tabel 9 tingkat inefisiensi ibu Zuraida berdasarkan masing-masing variabel input yang digunakan dalam usaha tani padi.

\section{Tabel 9}

Nilai Original, Target, Radial Movement dan Slack Movement Input Output Ibu Zuraida yang inefisiensi dengan tingkat efisiensi 0.737

\begin{tabular}{|l|cccc|}
\hline \multicolumn{1}{|c}{ Variabel } & $\begin{array}{c}\text { Original } \\
\text { value }\end{array}$ & $\begin{array}{c}\text { Target } \\
\text { value }\end{array}$ & $\begin{array}{c}\text { Radial } \\
\text { movement }\end{array}$ & $\begin{array}{c}\text { Slack } \\
\text { movement }\end{array}$ \\
\hline Produksi & 3000.000 & 3400.000 & 0.000 & 400.000 \\
Pupuk Urea & 50.000 & 30.000 & -13.158 & -6.842 \\
Pupuk NPK & 50.000 & 30.000 & -13.158 & -6.842 \\
Pupuk SP-36 & 25.000 & 10.000 & -6.579 & -8.421 \\
Insektisida & 114.000 & 84.000 & -30.000 & 0.000 \\
Benih & 20.000 & 10.000 & -5.263 & -4.737 \\
\hline
\end{tabular}

Sumber : Hasil olah data, 2019

Pada tabel 9 diatas dapat dijelaskan penggunaan input ibu Zuraida mengalami inefisiensi pada seluruh input yang digunakan yaitu pupuk Urea, pupuk NPK, pupuk SP-36, insektisida dan benih.

Variabel input pertama dan kedua yaitu pupuk urea dan pupuk NPK memiliki original value sebesar $50 \mathrm{~kg}$ dengan target value sebesar $30 \mathrm{~kg}$. Terlihat bahwa original value lebih tinggi dari pada target value, maka agar penggunaan pupuk urea dan pupuk NPK lebih efisien harus dikurangi sebesar $13.1 \mathrm{~kg}$.

Original value yang dimiliki oleh variabel input ketiga yaitu pupuk SP-36 sebesar $25 \mathrm{~kg}$ dan 
target value nya sebesar $10 \mathrm{~kg}$. Maka untuk lebih mengefisiensikan penggunaan pupuk SP-36 harus dikurangi sebesar $6.6 \mathrm{~kg}$.

Variabel input keempat yaitu insektisida memiliki original value sebesar $114 \mathrm{ml}$ dengan target value sebesar $84 \mathrm{ml}$. Terlihat bahwa original value lebih tinggi dari pada target value, maka agar penggunaan insektisida lebih efisien harus dikurangi sebesar $30 \mathrm{ml}$.

Variabel input kelima yaitu benih memiliki original value sebesar $20 \mathrm{~kg}$ dengan target value sebesar $10 \mathrm{~kg}$. Terlihat bahwa original value lebih tinggi dari pada target value, maka agar penggunaan benih lebih efisien harus dikurangi sebesar $5.3 \mathrm{~kg}$.

\section{Raziah Hasyim}

Berdasarkan pengujian yang telah dilakukan petani yang bernama Raziah Hasyim belum mencapai skala yang efisien, dikarenakan penggunaan input yang belum maksimal, sehingga menyebabkan output yang dihasilkan juga belum maksimal.

Berikut dapat dilihat pada tabel 11 tingkat inefisiensi ibu Raziah Hasyim berdasarkan masingmasing variabel input yang digunakan dalam usaha tani padi.

\section{Tabel 11}

Nilai Original, Target, Radial Movement dan Slack Movement Input Output Ibu Raziah Hasyimyang inefisiensi dengan tingkat efisiensi 0.627

\begin{tabular}{|l|cccc|}
\hline \multicolumn{1}{|c|}{ Variabel } & $\begin{array}{c}\text { Original } \\
\text { value }\end{array}$ & $\begin{array}{c}\text { Target } \\
\text { value }\end{array}$ & $\begin{array}{c}\text { Radial } \\
\text { movement }\end{array}$ & $\begin{array}{c}\text { Slack } \\
\text { movemen } \\
t\end{array}$ \\
\hline Produksi & 3000.000 & 3400.000 & 0.000 & 400.000 \\
Pupuk Urea & 50.000 & 30.000 & -18.657 & -1.343 \\
Pupuk NPK & 50.000 & 30.000 & -18.657 & -1.343 \\
Pupuk SP-36 & 50.000 & 10.000 & -18.657 & -21.343 \\
Insektisida & 134.000 & 84.000 & -50.000 & 0.000 \\
Benih & 20.000 & 10.000 & -7.463 & -2.537 \\
\hline
\end{tabular}

Sumber : Hasil olah data, 2019

Pada tabel 11 diatas dapat dijelaskan penggunaan input ibu Raziah Hasyim mengalami inefisiensi pada seluruh input yang digunakan yaitu pupuk Urea, pupuk NPK, pupuk SP-36, insektisida dan benih.

Variabel input pertama dan kedua yaitu pupuk urea dan pupuk NPK memiliki original value sebesar $50 \mathrm{~kg}$ dengan target value sebesar $30 \mathrm{~kg}$. Terlihat bahwa original value lebih tinggi dari pada target value, maka agar penggunaan pupuk urea dan pupuk NPK lebih efisien harus dikurangi sebesar $18.7 \mathrm{~kg}$.

Original value yang dimiliki oleh variabel input ketiga yaitu pupuk SP-36 sebesar $50 \mathrm{~kg}$ dan target value nya sebesar $10 \mathrm{~kg}$. Maka untuk lebih mengefisiensikan penggunaan pupuk SP-36 harus dikurangi sebesar $18.7 \mathrm{~kg}$.

Variabel input keempat yaitu insektisida memiliki original value sebesar $134 \mathrm{ml}$ dengan target value sebesar $84 \mathrm{ml}$. Terlihat bahwa original value lebih tinggi dari pada target value, maka agar penggunaan insektisida lebih efisien harus dikurangi sebesar $50 \mathrm{ml}$.
Variabel input kelima yaitu benih memiliki original value sebesar $20 \mathrm{~kg}$ dengan target value sebesar $10 \mathrm{~kg}$. Terlihat bahwa original value lebih tinggi dari pada target value, maka agar penggunaan benih lebih efisien harus dikurangi sebesar $7.4 \mathrm{~kg}$.

\section{Muhammad Yusuf}

Berdasarkan pengujian yang telah dilakukan petani yang bernama Muhammad Yusuf belum mencapai skala yang efisien, dikarenakan penggunaan input yang belum maksimal, sehingga menyebabkan output yang dihasilkan juga belum maksimal.

Berikut dapat dilihat pada tabel 12 tingkat inefisiensi bapak Muhammad Yusuf berdasarkan masing-masing variabel input yang digunakan dalam usaha tani padi.

Tabel 12

Nilai Original, Target, Radial Movement dan Slack Movement Input Output bapak Muhammad Yusufyang inefisiensi dengan tingkat efisiensi 0.882

\begin{tabular}{|l|cccc|}
\hline \multicolumn{1}{|c}{ Variabel } & $\begin{array}{c}\text { Original } \\
\text { value }\end{array}$ & $\begin{array}{l}\text { Target } \\
\text { value }\end{array}$ & $\begin{array}{c}\text { Radial } \\
\text { movement }\end{array}$ & $\begin{array}{c}\text { Slack } \\
\text { movement }\end{array}$ \\
\hline Produksi & 2800.000 & 2971.454 & 0.000 & 171.454 \\
Pupuk Urea & 50.000 & 44.118 & -5.882 & 0.000 \\
Pupuk NPK & 30.000 & 26.471 & -3.529 & 0.000 \\
Pupuk SP-36 & 20.000 & 16.428 & -2.353 & -1.219 \\
Insektisida & 206.000 & 169.210 & -24.235 & -12.554 \\
Benih & 20.000 & 14.285 & -2.353 & -3.362 \\
\hline
\end{tabular}

Sumber : Hasil olah data, 2019

Pada tabel 12 diatas dapat dijelaskan penggunaan input bapak Muhammad Yusuf mengalami inefisiensi pada seluruh input yang digunakan yaitu pupuk Urea, pupuk NPK, pupuk SP-36, insektisida dan benih.

Variabel input pertama yaitu pupuk urea memiliki original value sebesar $50 \mathrm{~kg}$ dengan target value sebesar $44 \mathrm{~kg}$. Terlihat bahwa original value lebih tinggi dari pada target value, maka agar penggunaan pupuk urea lebih efisien harus dikurangi sebesar $5.9 \mathrm{~kg}$.

Variabel input kedua yaitu pupuk NPK memiliki original value sebesar $30 \mathrm{~kg}$ dengan target value sebesar $26 \mathrm{~kg}$. Terlihat bahwa original value lebih tinggi dari pada target value, maka agar penggunaan pupuk NPK lebih efisien harus dikurangi sebesar $3.5 \mathrm{~kg}$.

Original value yang dimiliki oleh variabel input ketiga yaitu pupuk SP-36 sebesar $20 \mathrm{~kg}$ dan target value nya sebesar $16 \mathrm{~kg}$. Maka untuk lebih mengefisiensikan penggunaan pupuk SP-36 harus dikurangi sebesar $2.3 \mathrm{~kg}$.

Variabel input keempat yaitu insektisida memiliki original value sebesar $206 \mathrm{ml}$ dengan target value sebesar $169 \mathrm{ml}$. Terlihat bahwa original value lebih tinggi dari pada target value, maka agar penggunaan insektisida lebih efisien harus dikurangi sebesar $24.2 \mathrm{ml}$.

Variabel input kelima yaitu benih memiliki original value sebesar $20 \mathrm{~kg}$ dengan target value sebesar $14 \mathrm{~kg}$. Terlihat bahwa original value lebih 
tinggi dari pada target value, maka agar penggunaan benih lebih efisien harus dikurangi sebesar $2.3 \mathrm{~kg}$.

\section{Zainun}

Berdasarkan pengujian yang telah dilakukan petani yang bernama Zainun belum mencapai skala yang efisien, dikarenakan penggunaan input yang belum maksimal, sehingga menyebabkan output yang dihasilkan juga belum maksimal.

Berikut dapat dilihat pada tabel 13 tingkat inefisiensi ibu Zainun berdasarkan masing-masing variabel input yang digunakan dalam usaha tani padi.

\section{Tabel 13}

Nilai Original, Target, Radial Movement dan Slack Movement Input Output Ibu Zainunyang inefisiensi

\begin{tabular}{|l|cccc|}
\hline \multicolumn{5}{|c|}{ dengan tingkat efisiensi 0.627 } \\
\hline & $\begin{array}{c}\text { Original } \\
\text { value }\end{array}$ & $\begin{array}{c}\text { Target } \\
\text { value }\end{array}$ & $\begin{array}{c}\text { Radial } \\
\text { movement }\end{array}$ & $\begin{array}{c}\text { Slack } \\
\text { movement }\end{array}$ \\
\hline Produksi & 2600.000 & 3400.000 & 0.000 & 400.000 \\
Pupuk Urea & 50.000 & 30.000 & -18.657 & -1.343 \\
Pupuk NPK & 50.000 & 30.000 & -18.657 & -1.343 \\
Pupuk SP- & 20.000 & 10.000 & -18.657 & -21.343 \\
36 & 134.000 & 84.000 & -50.000 & 0.000 \\
Insektisida & 20.000 & 10.000 & -7.463 & -2.537 \\
Benih & & & & \\
\hline
\end{tabular}

Sumber : Hasil olah data, 2019

Pada tabel 13 diatas dapat dijelaskan penggunaan input ibu Zainun mengalami inefisiensi pada seluruh input yang digunakan yaitu pupuk Urea, pupuk NPK, pupuk SP-36, insektisida dan benih.

Variabel input pertama dan kedua yaitu pupuk urea dan pupuk NPK memiliki original value sebesar $50 \mathrm{~kg}$ dengan target value sebesar $30 \mathrm{~kg}$. Terlihat bahwa original value lebih tinggi dari pada target value, maka agar penggunaan pupuk urea dan pupuk NPK lebih efisien harus dikurangi sebesar $18.7 \mathrm{~kg}$.

Original value yang dimiliki oleh variabel input ketiga yaitu pupuk SP-36 sebesar $50 \mathrm{~kg}$ dan target value nya sebesar $10 \mathrm{~kg}$. Maka untuk lebih mengefisiensikan penggunaan pupuk SP-36 harus dikurangi sebesar $18.7 \mathrm{~kg}$.

Variabel input keempat yaitu insektisida memiliki original value sebesar $134 \mathrm{ml}$ dengan target value sebesar $84 \mathrm{ml}$. Terlihat bahwa original value lebih tinggi dari pada target value, maka agar penggunaan insektisida lebih efisien harus dikurangi sebesar $50 \mathrm{ml}$.

Variabel input kelima yaitu benih memiliki original value sebesar $20 \mathrm{~kg}$ dengan target value sebesar $10 \mathrm{~kg}$. Terlihat bahwa original value lebih tinggi dari pada target value, maka agar penggunaan benih lebih efisien harus dikurangi sebesar $7.4 \mathrm{~kg}$.

\section{Luqman Nafi}

Berdasarkan pengujian yang telah dilakukan petani yang bernama Luqman Nafi belum mencapai skala yang efisien, dikarenakan penggunaan input yang belum maksimal, sehingga menyebabkan output yang dihasilkan juga belum maksimal.

Berikut dapat dilihat pada tabel 4.14 tingkat inefisiensi bapak Luqman Nafi berdasarkan masing- masing variabel input yang digunakan dalam usaha tani padi.

\section{Tabel 14}

Nilai Original, Target, Radial Movement dan Slack Movement Input Output bapak Luqman Nafi yang inefisiensi dengan tingkat efisiensi 0.600

\begin{tabular}{|l|cccc|}
\hline \multicolumn{1}{|c|}{ Variabel } & $\begin{array}{c}\text { Original } \\
\text { value }\end{array}$ & $\begin{array}{c}\text { Target } \\
\text { value }\end{array}$ & $\begin{array}{c}\text { Radial } \\
\text { movement }\end{array}$ & $\begin{array}{c}\text { Slack } \\
\text { movement }\end{array}$ \\
\hline Produksi & 2800.000 & 3400.000 & 0.000 & 600.000 \\
Pupuk Urea & 50.000 & 30.000 & -20.000 & 0.000 \\
Pupuk NPK & 50.000 & 30.000 & -20.000 & 0.000 \\
Pupuk SP- & 50.000 & 10.000 & -20.000 & -20.000 \\
36 & 172.000 & 84.000 & -68.800 & -19.200 \\
Insektisida & 20.000 & 10.000 & -8.000 & -2.000 \\
Benih & & & & \\
\hline
\end{tabular}

Sumber : Hasil olah data, 2019

Pada tabel 14 diatas dapat dijelaskan penggunaan input bapak Luqman Nafi mengalami inefisiensi pada seluruh input yang digunakan yaitu pupuk Urea, pupuk NPK, pupuk SP-36, insektisida dan benih.

Variabel input pertama dan kedua yaitu pupuk urea dan pupuk NPK memiliki original value sebesar $50 \mathrm{~kg}$ dengan target value sebesar $30 \mathrm{~kg}$. Terlihat bahwa original value lebih tinggi dari pada target value, maka agar penggunaan pupuk urea dan pupuk NPK lebih efisien harus dikurangi sebesar $20 \mathrm{~kg}$.

Original value yang dimiliki oleh variabel input ketiga yaitu pupuk SP-36 sebesar $50 \mathrm{~kg}$ dan target value nya sebesar $10 \mathrm{~kg}$. Maka untuk lebih mengefisiensikan penggunaan pupuk SP-36 harus dikurangi sebesar $20 \mathrm{~kg}$.

Variabel input keempat yaitu insektisida memiliki original value sebesar $172 \mathrm{ml}$ dengan target value sebesar $84 \mathrm{ml}$. Terlihat bahwa original value lebih tinggi dari pada target value, maka agar penggunaan insektisida lebih efisien harus dikurangi sebesar $68.8 \mathrm{ml}$.

Variabel input kelima yaitu benih memiliki original value sebesar $20 \mathrm{~kg}$ dengan target value sebesar $10 \mathrm{~kg}$. Terlihat bahwa original value lebih tinggi dari pada target value, maka agar penggunaan benih lebih efisien harus dikurangi sebesar $8 \mathrm{~kg}$.

\section{Upaya peningkatan efisiensi Petani Pemilik Lahan di Desa Meunasah Panton Labu}

Berdasarkan hasil pengujian yang telah dilakukan dapat dilihat bahwa nilai skala efisiensi pada petani pemilik lahan di desa Meunasah Panton Labu yang berada dibawah angka satu $(<1)$ ada 6 petani pemilik lahan yaitu Nur Wahidah, Muslem, Nur Baidah, Heriyati, Rahmaniah dan Nurjannah.

\section{Nur Wahidah}

Berdasarkan hasil penelitian yang telah dilakukan sebelumnya petani yang bernama Nur Wahidah belum mencapai skala yang efisien, dikarenakan penggunaan input yang belum maksimal, sehingga menyebabkan output yang dihasilkan juga belum maksimal. 
Berikut dapat dilihat pada tabel 4.15 tingkat inefisiensi ibu Nur Wahidah, berdasarkan masingmasing variabel input yang digunakan dalam usaha tani padi.

Tabel 15

Nilai Original, Target, Radial Movement dan Slack Movement Input Output Ibu Nurwahidah yang inefisiensi dengan tingkat efisiensi 0.531

\begin{tabular}{|l|cccc|}
\hline \multicolumn{1}{|c|}{ Variabel } & $\begin{array}{c}\text { Original } \\
\text { value }\end{array}$ & $\begin{array}{l}\text { Target } \\
\text { value }\end{array}$ & $\begin{array}{c}\text { Radial } \\
\text { movement }\end{array}$ & $\begin{array}{c}\text { Slack } \\
\text { movement }\end{array}$ \\
\hline Produksi & 2400.000 & 3231.250 & 0.000 & 831.250 \\
Pupuk Urea & 50.000 & 26.563 & -23.437 & 0.000 \\
Pupuk NPK & 50.000 & 26.563 & -23.437 & 0.000 \\
Pupuk SP-36 & 50.000 & 13.437 & -23.437 & -13.125 \\
Insektisida & 314.000 & 86.875 & -147.187 & -79.938 \\
Benih & 20.000 & 10.625 & -9.375 & 0.000 \\
\hline
\end{tabular}

Sumber : Hasil olah data, 2019

Pada tabel 15 diatas dapat dijelaskan penggunaan input ibu Nur Wahidah mengalami inefisiensi pada seluruh input yang digunakan yaitu pupuk Urea, pupuk NPK, pupuk SP-36, insektisida dan benih.

Variabel input pertama dan kedua yaitu pupuk urea dan pupuk NPK memiliki original value sebesar $50 \mathrm{~kg}$ dengan target value sebesar $26.6 \mathrm{~kg}$. Terlihat bahwa original value lebih tinggi dari pada target value, maka agar penggunaan pupuk urea dan pupuk NPK lebih efisien harus dikurangi sebesar $23.4 \mathrm{~kg}$.

Original value yang dimiliki oleh variabel input ketiga yaitu pupuk SP-36 sebesar $50 \mathrm{~kg}$ dan target value nya sebesar $13.4 \mathrm{~kg}$. Maka untuk lebih mengefisiensikan penggunaan pupuk SP-36 harus dikurangi sebesar $23.4 \mathrm{~kg}$.

Variabel input keempat yaitu insektisida memiliki original value sebesar $314 \mathrm{ml}$ dengan target value sebesar $86.9 \mathrm{ml}$. Terlihat bahwa original value lebih tinggi dari pada target value, maka agar penggunaan insektisida lebih efisien harus dikurangi sebesar $147 \mathrm{ml}$.

Variabel input kelima yaitu benih memiliki original value sebesar $20 \mathrm{~kg}$ dengan target value sebesar $10 \mathrm{~kg}$. Terlihat bahwa original value lebih tinggi dari pada target value, maka agar penggunaan benih lebih efisien harus dikurangi sebesar $9 \mathrm{~kg}$.

\section{Muslem}

Berdasarkan hasil penelitian yang telah dilakukan sebelumnya petani yang bernama Muslem belum mencapai skala yang efisien, dikarenakan penggunaan input yang belum maksimal, sehingga menyebabkan output yang dihasilkan juga belum maksimal.

Berikut dapat dilihat pada tabel 16 tingkat inefisiensi bapak Muslem berdasarkan masing-masing variabel input yang digunakan dalam usaha tani padi.

\section{Tabel 16}

Nilai Original, Target, Radial Movement dan Slack Movement Input Output Bapak Muslem yang inefisiensi dengan tingkat efisiensi $\mathbf{0 . 5 3 1}$

\begin{tabular}{|lcccc|}
\hline \multicolumn{1}{|c|}{ Variabel } & $\begin{array}{c}\text { Original } \\
\text { value }\end{array}$ & $\begin{array}{c}\text { Target } \\
\text { value }\end{array}$ & $\begin{array}{c}\text { Radial } \\
\text { movement }\end{array}$ & $\begin{array}{c}\text { Slack } \\
\text { movement }\end{array}$ \\
\hline Produksi & 2800.000 & 3231.250 & 0.000 & 431.250 \\
Pupuk Urea & 50.000 & 26.563 & -23.437 & 0.000 \\
Pupuk NPK & 50.000 & 26.563 & -23.437 & 0.000 \\
Pupuk SP-36 & 30.000 & 13.437 & -14.062 & -2.500 \\
Insektisida & 254.000 & 86.875 & -119.062 & -48.063 \\
Benih & 20.000 & 10.625 & -9.375 & 0.000 \\
\hline
\end{tabular}

Sumber : Hasil olah data, 2019

Pada tabel 16 diatas dapat dijelaskan penggunaan input bapak Muslem mengalami inefisiensi pada seluruh input yang digunakan yaitu pupuk Urea, pupuk NPK, pupuk SP-36, insektisida dan benih.

Variabel input pertama dan kedua yaitu pupuk urea dan pupuk NPK memiliki original value sebesar $50 \mathrm{~kg}$ dengan target value sebesar $26.6 \mathrm{~kg}$. Terlihat bahwa original value lebih tinggi dari pada target value, maka agar penggunaan pupuk urea dan pupuk NPK lebih efisien harus dikurangi sebesar $23.4 \mathrm{~kg}$.

Original value yang dimiliki oleh variabel input ketiga yaitu pupuk SP-36 sebesar $30 \mathrm{~kg}$ dan target value nya sebesar $13.4 \mathrm{~kg}$. Maka untuk lebih mengefisiensikan penggunaan pupuk SP-36 harus dikurangi sebesar $14 \mathrm{~kg}$.

Variabel input keempat yaitu insektisida memiliki original value sebesar $254 \mathrm{ml}$ dengan target value sebesar $86.9 \mathrm{ml}$. Terlihat bahwa original value lebih tinggi dari pada target value, maka agar penggunaan insektisida lebih efisien harus dikurangi sebesar $119 \mathrm{ml}$.

Variabel input kelima yaitu benih memiliki original value sebesar $20 \mathrm{~kg}$ dengan target value sebesar $10 \mathrm{~kg}$. Terlihat bahwa original value lebih tinggi dari pada target value, maka agar penggunaan benih lebih efisien harus dikurangi sebesar $9.3 \mathrm{~kg}$.

\section{Nur Baidah}

Berdasarkan hasil penelitian yang telah dilakukan sebelumnya petani yang bernama Nur Baidah belum mencapai skala yang efisien, dikarenakan penggunaan input yang belum maksimal, sehingga menyebabkan output yang dihasilkan juga belum maksimal.

Berikut dapat dilihat pada tabel 17 tingkat inefisiensi ibu Nur Wahidah berdasarkan masingmasing variabel input yang digunakan dalam usaha tani padi. 
Tabel 17

Nilai Original, Target, Radial Movement dan Slack Movement Input Output Ibu Nur Baidah yang inefisiensi dengan tingkat efisiensi 0.807

\begin{tabular}{|l|cccc|}
\hline \multicolumn{1}{|c|}{ Variabel } & $\begin{array}{c}\text { Original } \\
\text { value }\end{array}$ & $\begin{array}{c}\text { Target } \\
\text { value }\end{array}$ & $\begin{array}{c}\text { Radial } \\
\text { movement }\end{array}$ & $\begin{array}{c}\text { Slack } \\
\text { movement }\end{array}$ \\
\hline Produksi & 2800.000 & 2947.368 & 0.000 & 147.368 \\
Pupuk Urea & 50.000 & 24.737 & -9.649 & -15.614 \\
Pupuk NPK & 30.000 & 24.737 & -5.789 & 0.000 \\
Pupuk SP-36 & 20.000 & 15.789 & -3.860 & -0.351 \\
Insektisida & 102.000 & 82.316 & -19.684 & 0.000 \\
Benih & 15.000 & 12.105 & -2.895 & 0.000 \\
\hline
\end{tabular}

Sumber : Hasil olah data, 2019

Pada tabel 17 diatas dapat dijelaskan penggunaan input ibu Nur Baidah mengalami inefisiensi pada seluruh input yang digunakan yaitu pupuk Urea, pupuk NPK, pupuk SP-36, insektisida dan benih.

Variabel input pertama yaitu pupuk urea memiliki original value sebesar $50 \mathrm{~kg}$ dengan target value sebesar $24.8 \mathrm{~kg}$. Terlihat bahwa original value lebih tinggi dari pada target value, maka agar penggunaan pupuk urea lebih efisien harus dikurangi sebesar $9.7 \mathrm{~kg}$.

Variabel input kedua yaitu pupuk NPK memiliki original value sebesar $30 \mathrm{~kg}$ dengan target value sebesar $24 \mathrm{~kg}$. Terlihat bahwa original value lebih tinggi dari pada target value, maka agar penggunaan pupuk NPK lebih efisien harus dikurangi sebesar $5.8 \mathrm{~kg}$.

Original value yang dimiliki oleh variabel input ketiga yaitu pupuk SP-36 sebesar $20 \mathrm{~kg}$ dan target value nya sebesar $15.8 \mathrm{~kg}$. Maka untuk lebih mengefisiensikan penggunaan pupuk SP-36 harus dikurangi sebesar $3.9 \mathrm{~kg}$.

Variabel input keempat yaitu insektisida memiliki original value sebesar $102 \mathrm{ml}$ dengan target value sebesar $82 \mathrm{ml}$. Terlihat bahwa original value lebih tinggi dari pada target value, maka agar penggunaan insektisida lebih efisien harus dikurangi sebesar $19.7 \mathrm{ml}$.

Variabel input kelima yaitu benih memiliki original value sebesar $15 \mathrm{~kg}$ dengan target value sebesar $12 \mathrm{~kg}$. Terlihat bahwa original value lebih tinggi dari pada target value, maka agar penggunaan benih lebih efisien harus dikurangi sebesar $2.9 \mathrm{~kg}$.

\section{Heriyati}

Berdasarkan hasil penelitian yang telah dilakukan sebelumnya petani yang bernama Heriyati belum mencapai skala yang efisien, dikarenakan penggunaan input yang belum maksimal, sehingga menyebabkan output yang dihasilkan juga belum maksimal.

Berikut dapat dilihat pada tabel 18 tingkat inefisiensi ibu Heriyati berdasarkan masing-masing variabel input yang digunakan dalam usaha tani padi.
Tabel 18

Nilai Original, Target, Radial Movement dan Slack Movement Input Output Ibu Heriyati yang inefisiensi dengan tingkat efisiensi 0.717

\begin{tabular}{|l|cccc|}
\hline \multicolumn{1}{|c|}{ Variabel } & $\begin{array}{c}\text { Original } \\
\text { value }\end{array}$ & $\begin{array}{c}\text { Target } \\
\text { value }\end{array}$ & $\begin{array}{c}\text { Radial } \\
\text { movement }\end{array}$ & $\begin{array}{c}\text { Slack } \\
\text { movement }\end{array}$ \\
\hline Produksi & 2800.000 & 3030.435 & 0.000 & 30.435 \\
Pupuk Urea & 50.000 & 35.870 & -14.130 & 0.000 \\
Pupuk NPK & 30.000 & 21.522 & -8.478 & 0.000 \\
Pupuk SP- & 20.000 & 14.348 & -5.652 & 0.000 \\
$\begin{array}{l}\text { I6 } \\
\text { Insektisida }\end{array}$ & 102.000 & 90.435 & -36.739 & -2.826 \\
Benih & 15.000 & 14.348 & -5.652 & 0.000 \\
\hline
\end{tabular}

Sumber : Hasil olah data, 2019

Pada tabel 18 diatas dapat dijelaskan penggunaan input ibu Heriyati mengalami inefisiensi pada seluruh input yang digunakan yaitu pupuk Urea, pupuk NPK, pupuk SP-36, insektisida dan benih.

Variabel input pertama yaitu pupuk urea memiliki original value sebesar $50 \mathrm{~kg}$ dengan target value sebesar $35.9 \mathrm{~kg}$. Terlihat bahwa original value lebih tinggi dari pada target value, maka agar penggunaan pupuk urea lebih efisien harus dikurangi sebesar $14 \mathrm{~kg}$.

Variabel input kedua yaitu pupuk NPK memiliki original value sebesar $30 \mathrm{~kg}$ dengan target value sebesar $21.5 \mathrm{~kg}$. Terlihat bahwa original value lebih tinggi dari pada target value, maka agar penggunaan pupuk NPK lebih efisien harus dikurangi sebesar $8.5 \mathrm{~kg}$.

Original value yang dimiliki oleh variabel input ketiga yaitu pupuk SP-36 sebesar $20 \mathrm{~kg}$ dan target value nya sebesar $14 \mathrm{~kg}$. Maka untuk lebih mengefisiensikan penggunaan pupuk SP-36 harus dikurangi sebesar $5.7 \mathrm{~kg}$.

Variabel input keempat yaitu insektisida memiliki original value sebesar $102 \mathrm{ml}$ dengan target value sebesar $90 \mathrm{ml}$. Terlihat bahwa original value lebih tinggi dari pada target value, maka agar penggunaan insektisida lebih efisien harus dikurangi sebesar $36.8 \mathrm{ml}$.

Variabel input kelima yaitu benih memiliki original value sebesar $15 \mathrm{~kg}$ dengan target value sebesar $14 \mathrm{~kg}$. Terlihat bahwa original value lebih tinggi dari pada target value, maka agar penggunaan benih lebih efisien harus dikurangi sebesar $5.7 \mathrm{~kg}$.

\section{Rahmaniah}

Berdasarkan hasil penelitian yang telah dilakukan sebelumnya petani yang bernama Rahmaniah belum mencapai skala yang efisien, dikarenakan penggunaan input yang belum maksimal, sehingga menyebabkan output yang dihasilkan juga belum maksimal.

Berikut dapat dilihat pada tabel 19 tingkat inefisiensi ibu Rahmaniah berdasarkan masing-masing variabel input yang digunakan dalam usaha tani padi. 
Tabel 19

Nilai Original, Target, Radial Movement dan Slack Movement Input Output Ibu Rahmaniah yang inefisiensi dengan tingkat efisiensi 0.760

\begin{tabular}{|l|cccc|}
\hline Variabel & $\begin{array}{c}\text { Original } \\
\text { value }\end{array}$ & $\begin{array}{c}\text { Target } \\
\text { value }\end{array}$ & $\begin{array}{c}\text { Radial } \\
\text { movement }\end{array}$ & $\begin{array}{c}\text { Slack } \\
\text { movement }\end{array}$ \\
\hline Produksi & 2600.000 & 2760.000 & 0.000 & 160.000 \\
Pupuk Urea & 50.000 & 38.000 & -12.000 & 0.000 \\
Pupuk NPK & 50.000 & 38.000 & -12.000 & 0.000 \\
Pupuk SP- & 50.000 & 14.000 & -12.000 & -24.000 \\
36 & 90.000 & 68.400 & -21.600 & 0.000 \\
Insektisida & 20.000 & 15.000 & -4.800 & -0.200 \\
\hline
\end{tabular}

Sumber : Hasil olah data, 2019

Pada tabel 19 diatas dapat dijelaskan penggunaan input ibu Rahmaniah mengalami inefisiensi pada seluruh input yang digunakan yaitu pupuk Urea, pupuk NPK, pupuk SP-36, insektisida dan benih.

Variabel input pertama dan kedua yaitu pupuk urea dan pupuk NPK memiliki original value sebesar $50 \mathrm{~kg}$ dengan target value sebesar $38 \mathrm{~kg}$. Terlihat bahwa original value lebih tinggi dari pada target value, maka agar penggunaan pupuk urea dan pupuk NPK lebih efisien harus dikurangi sebesar $12 \mathrm{~kg}$.

Original value yang dimiliki oleh variabel input ketiga yaitu pupuk SP-36 sebesar $50 \mathrm{~kg}$ dan target value nya sebesar $14 \mathrm{~kg}$. Maka untuk lebih mengefisiensikan penggunaan pupuk SP-36 harus dikurangi sebesar $12 \mathrm{~kg}$.

Variabel input keempat yaitu insektisida memiliki original value sebesar $90 \mathrm{ml}$ dengan target value sebesar $68 \mathrm{ml}$. Terlihat bahwa original value lebih tinggi dari pada target value, maka agar penggunaan insektisida lebih efisien harus dikurangi sebesar $21.6 \mathrm{ml}$.

Variabel input kelima yaitu benih memiliki original value sebesar $20 \mathrm{~kg}$ dengan target value sebesar $15 \mathrm{~kg}$. Terlihat bahwa original value lebih tinggi dari pada target value, maka agar penggunaan benih lebih efisien harus dikurangi sebesar $4.8 \mathrm{~kg}$.

\section{Nurjannah}

Berdasarkan hasil penelitian yang telah dilakukan sebelumnya petani yang bernama Nurjannah belum mencapai skala yang efisien, dikarenakan penggunaan input yang belum maksimal, sehingga menyebabkan output yang dihasilkan juga belum maksimal.

Berikut dapat dilihat pada tabel 20 tingkat inefisiensi ibu Nurjannah berdasarkan masing-masing variabel input yang digunakan dalam usaha tani padi.

Tabel 20

Nilai Original, Target, Radial Movement dan Slack Movement Input Output Ibu Nurjannahyang inefisiensi dengan tingkat efisiensi 0.541

\begin{tabular}{|l|cccc|}
\hline Variabel & $\begin{array}{c}\text { Original } \\
\text { value }\end{array}$ & $\begin{array}{c}\text { Target } \\
\text { value }\end{array}$ & $\begin{array}{c}\text { Radial } \\
\text { movement }\end{array}$ & $\begin{array}{c}\text { Slack } \\
\text { movement }\end{array}$ \\
\hline Produksi & 2800.000 & 3209.412 & 0.000 & 409.412 \\
\hline
\end{tabular}

$\begin{array}{|lcccc|}\text { Pupuk Urea } & 50.000 & 23.882 & -22.941 & -3.176 \\ \text { Pupuk NPK } & 50.000 & 27.059 & -22.941 & 0.000 \\ \text { Pupuk SP- } & 50.000 & 12.941 & -22.941 & -14.118 \\ 36 & & & -70.659 & 0.000 \\ \text { Insektisida } & 154.000 & 83.341 & -9.176 & 0.000 \\ \text { Benih } & 20.000 & 10.824 & \end{array}$

Sumber : Hasil olah data, 2019

Pada tabel 20 diatas dapat dijelaskan penggunaan input ibu Nurjannah mengalami inefisiensi pada seluruh input yang digunakan yaitu pupuk Urea, pupuk NPK, pupuk SP-36, insektisida dan benih.

Variabel input pertama yaitu pupuk urea memiliki original value sebesar $50 \mathrm{~kg}$ dengan target value sebesar $23.9 \mathrm{~kg}$. Terlihat bahwa original value lebih tinggi dari pada target value, maka agar penggunaan pupuk urea lebih efisien harus dikurangi sebesar $23 \mathrm{~kg}$.

Variabel input kedua yaitu pupuk NPK memiliki original value sebesar $50 \mathrm{~kg}$ dengan target value sebesar $27 \mathrm{~kg}$. Terlihat bahwa original value lebih tinggi dari pada target value, maka agar penggunaan pupuk NPK lebih efisien harus dikurangi sebesar $23 \mathrm{~kg}$.

Original value yang dimiliki oleh variabel input ketiga yaitu pupuk SP-36 sebesar $50 \mathrm{~kg}$ dan target value nya sebesar $13 \mathrm{~kg}$. Maka untuk lebih mengefisiensikan penggunaan pupuk SP-36 harus dikurangi sebesar $23 \mathrm{~kg}$.

Variabel input keempat yaitu insektisida memiliki original value sebesar $154 \mathrm{ml}$ dengan target value sebesar $83 \mathrm{ml}$. Terlihat bahwa original value lebih tinggi dari pada target value, maka agar penggunaan insektisida lebih efisien harus dikurangi sebesar $71 \mathrm{ml}$.

Variabel input kelima yaitu benih memiliki original value sebesar $20 \mathrm{~kg}$ dengan target value sebesar $11 \mathrm{~kg}$. Terlihat bahwa original value lebih tinggi dari pada target value, maka agar penggunaan benih lebih efisien harus dikurangi sebesar $9.2 \mathrm{~kg}$.

Hal ini sejalan dengan penelitian yang dilakukakan oleh ( Firmana dkk, 2016) menunjukkan bahwa, Petani dapat mengurangi penggunaan pupuk urea sebanyak $19,173 \mathrm{~kg}$, pupuk NPK sebanyak 19,319 kg, dan tenaga kerja sebanyak 1,385 HOK agar usahatani padi yang dilakukan efisien secara teknis.

Dan juga sejalan dengan Hasil panelitian (Hestina dkk, 2015) menunjukkan bahwa Petani di Jawa dapat mengurangi penggunaan urea sebanyak $6.75 \mathrm{~kg}$, NPK sebanyak $14.96 \mathrm{~kg}$, dan tenaga kerja sebanyak 7.45 HOK dan petani luar Jawa urea sebanyak $32.37 \mathrm{~kg}$, NPK sebanyak 6.01 $\mathrm{kg}$, dan tenaga kerja sebanyak 15.93 HOK agar usahatani padi dapat efisien secara teknis.

Sementara Hasil penelitian (Ambarawati dkk, 2012) menunjukkan bahwa input pupuk Urea, pupuk NPK (Phosnka dan Pelangi), pupuk organik dan tenaga kerja sudah efisien, sedangkan secara 
ekonomis penggunaan pestisida tidak efisien, maka perlu mengurangi jumlah penggunaan secara tepat jenis, dosis, waktu dan cara pemberian sehingga menghasilkan produksi padi yang optimal dan petani memperoleh keuntungan yang maksimum.

\section{PENUTUP}

\section{Kesimpulan}

Berdasarkan hasil penelitian dan pembahasan sebelumnya, adapun kesimpulan dari penelitian ini adalah sebagai berikut :

Petani dikatakan efisien secara teknis jika mampu menggunakan input seminimal mungkin untuk memperoleh output produksi yang maksimal. Dari 50 petani yang menjadi responden, rata-rata nilai efisiensi teknis sebesar 0.908. Petani padi di desa Meunasah panton labu yang telah efisien secara teknis sebanyak 34 petani (68\%) dari total petani responden.

Adapun petani yang memperoleh tingkat efisiensi lebih banyak berdasarkan target output yang telah dihasilkan ialah petani pemilik lahan, dimana petani pemilik lahan yang telah efisien secara teknis berjumlah 19 petani responden, sedangkan petani penggarap yang efisien secara teknis berjumlah 15 petani responden. Perbedaan tingkat efisiensi yang diperoleh disebabkan oleh perbedaan penggunaan input atau sarana produksi yang digunakan, serta juga pengunaan sarana produksi yang belum tepat sasaran, baik itu penggunaan pupuk, insektisida serta benih yang berlebihan.

\section{Saran}

Berdasarkan hasil penelitian yang telah dilakukan, maka dapat dikemukakan beberapa saran sebagai berikut :

1. Berdasarkan hasil penelitian ini ada 16 petani responden yang belum mencapai taraf efisien. Maka dari itu petani harus lebih memperhatikan kembali penggunaan sarana produksi, baik pupuk, insektisida dan benih yang harus tepat waktu dan tepat sasaran, karena dengan penggunaan sarana produksi yang tepat waktu dan tepat sasaran akan meningkatkan hasil produksi padi, bagi petani yang belum efisien secara teknis dapat mengurangi penggunaan input yang berlebihan agar dapat mencapai skala efisiensi.

2. Untuk meningkatkan hasil produksi pertaniansangat diperlukan adanya campur tangan pemerintah dalam hal penyuluhan di bidang pertanian agar petani yang belum efisien dalam pengunaan benih, pupuk dan insektisida agar menjadi lebih efisien.

3. Bagi peneliti selanjutnya, dapat menggunakan variabel-variabel sarana produksi yang lainnya, menambah jumlah desa serta menggunakan metode dan pendekatan yang lebih beragam untuk memperoleh hasil penilaian tingkat efisiesnsi usaha tani padi yang lebih beragam dan lebih terperinci.

\section{KEPUSTAKAAN}

Anonymous. (2012). Green Education Centre. http:// budidaya-sorgum.html Diakses tanggal 30 Juni 2012.

Anwar, Sanusi. (2011). Metode Penelitian Bisnis. Jakarta: Salemba Empat.

Bejo, Siswanto. (2011). Manajemen Tenaga Kerja Indonesia Pendekatan Administratif dan Operasional. Jakarta: Bumi Aksara.

BPS. (2010). Provinsi Aceh Dalam Angka Tahun 2010. Biro Pusat Statistik: Provinsi Aceh.

(2016). Provinsi Aceh Dalam Angka Tahun 2016. Biro Pusat Statistik: Kabupaten Aceh Utara.

Dinas Pertanian dan Tanaman Pangan Aceh Utara. (2011). Pemupukan Tanaman Padi Sawah. Kabupaten Aceh Utara.

Hanafie, Rita.(2010). Pengantar Ekonomi Pertanian. Penerbit ANDI. Yogyakarta.

Hanum, Chairani. (2008). Teknik Budidaya Tanaman: Jilid 1 Departemen Pendidikan Nasional. Jakarta: Buku Sekolah Elektronik.

Khakim, Ludfil, Dewi Hastuti, dkk. (2013). Pengaruh Lahan, Tenaga Kerja, Penggunaan Benih dan Penggunaan Pupuk terhadap Produksi Padi di Jawa Tengah. Jurnal Ilmu Pertanian. Vol. 9 No 1:71-79.

Respikasari., T, Ekowati., dan A, Setiadi. (2014).

Analisis Efisiensi Ekonomi Penggunaan Faktor-Faktor Produksi Usahatani Padi Sawah di Kabupaten Karanganyar. $J$. Agribisnis dan Agrowisata 5 (1) : 1-11.

Soekarwati. (2003). Prinsip Ekonomi

Pertanian.Jakarta: Raja Grafindo Persada.

Sugiyono. (2012).Metode Penelitian Bisnis. Bandung: Alfabeta. 
Sukirno, S. (2002). Pengantar Teori Mikro Ekonomi. Edisi Ketiga. Jakarta: Rajawali Press.

(2010).Makroekonomi Teori Pengantar. Edisi Ketiga. Jakarta: PT. Raja Grasindo Perseda.

Tulus, Tambunan. (2003). Perkembangan Sektor Pertanian di Indonesia, Beberapa Isu Penting.Jakarta : GhaliaIndonesia.

USDA, (2011). USDA National Nutrient Database for Standard Reference, Release 24. USDA. Download 29 September 2011.

Yusuf, A. (2010). Teknologi Budidaya Padi Sawah Mendukung. Sumatera Utara: SIPPT. BPTP. 